\title{
SPORT PARTICIPATION AFTER INJURY OF ANTERIOR CRUCIATE LIGAMENT
}

\author{
Bojan Ilić ${ }^{1}$, Aleksandra Nikolić ${ }^{2}$ and Dejan Ilić ${ }^{3}$ \\ ${ }^{1}$ „Ruđer Bošković“ Education Centre, Belgrade, Republic of Serbia \\ ${ }^{2}$ Faculty of Sport and Physical Education, Belgrade, Republic of Serbia \\ ${ }^{3}$ Faculty of Sport and Physical Education, Belgrade, Republic of Serbia
}

\section{Professional paper}

\section{SUMMARY}

One of the most common problems involving the knee joint is an anterior cruciate ligament injury or ACL tear. Of the four major knee ligaments of the knee, an ACL injury or rupture is the most debilitating knee ligament injury. Ligament injuries in the knee joint often lead to premature end of sport career in athletes. Treatment following ACL rupture can be operative or conservative. In both cases, main goal of patient is to reach the best functional level, without risk of re-injury or degenerative changes in knee joint. Return to high level of sport performance is the indicator of successfull treatment. Rehabilitation represents crucial part of threatment. Knowledge on healing processes and knee biomechanics after injury and recostruction, along with physiologial aspects of training processess, is very importmant for the construction of training programs. Current rehabilitation programs use immediate trainings, i.e. exercises for the increasement of range of motion. In most cases, rehabilitation programs are being created relative to time which is needed for the returnment to certain sport activities. In this article, we would like to provide an overview of the current strategies for sport participation and rehabilitation after ACL injury. Operation, along with completed rehabilitation program, which is sport-specific, should lead to functional stability of knee joint. Furthermore, adequate muscle strength and performance can be presented as main criterias for the returning to sport activities. Another factors, such as additional injuries, sociological and psychological barieres, can also influence the returnement to sport activities. Therefore, they should be considered durring rehabilitation process and evaluation of the treatment.

Keywords: physiotherapy,recovery, injuries, sport medicine, rehabilitation

\section{INTRODUCTION}

Elite athletes are exposed to greater risk of anterior cruciate ligament (ACL) injuries (Roos, Ornell, Gardsell et al., 1995; Bjordal, Arnly, Hannestad et al., 1997). Furthermore, risk of injury is greater among (Roos, Ornell, Gardsell et al., 1995; Bjordal, Arnly, Hannestad et al., 1997; Myklebust, Maehlum, Engebretsen et al., 1997; Hewett, Lindenfeld, Riccobene et al., 1999).

Injury of ACL lead to static and functional instability, which provoke changes in mouvement patterns (Berchuck, Andriacchi, Bach et al., 1990; Beard, Dodd, Trundle et al., 1994; Kvist \& Gillquist, 2001) and increase risk of suffering from osteoarthritis (Gillquist \& Messner, 1999). 
In most cases, ACL injuries lead to premature end of sport career (Roos, Ornell, Gardsell et al., 1995; Bjordal, Arnly, Hannestad et al., 1997). Study of (Roos, Ornell, Gardsell et al., 1995) showed that only $30 \%$ of football players were active 3 years after ACL injury.

Durring operation, after ACL injury, ruptured ligament is being replaced with graft in order to reduce anterior translation of tibia in sagital plane. The main purpose of recostrunction is to restore knee function, withount any pain and degenerative changes in relation to operation.

It is not neccessare to operate all athletes with ACL rupture. Most common criteria are age of the athlete, additional injuries of ligaments and menisci, functional and sport requirement in relation to knee, as well as readiness and willigness of the athlete to participate actively in post-operative rehabilitation.

\section{Knee joint}

The knee joint is one of the strongest and most important joints in the human body. It allows the lower leg to move relative to the thigh while supporting the body's weight. Movements at the knee joint are essential to many everyday activities, including walking, running, sitting and standing.

Knee joint consists of three bones, thigh bone (femur), kneecap (patella) and tibia. Tendons connect the knee bones to the leg muscles that move the knee joint. Ligaments join the knee bones and provide stability to the knee. Morphologicaly it can be said that knee is composed of patelofemoral and femorotibial joint, with two sections, external and internal.

Knee joint is protected with well inerved articulated tunica, which proximaly extends from articular surface of femur for patella (facies patellaris femoris) and forms suprapatellar knee pocket (Fulkerson \& Hungerford, 1990).

\subsection{Anterior cruciate ligament}

Anterior cruciate ligament is interarticular and extrasynovial articular structure. It originates from a wide base on the anterior aspect of the tibia and inserts into the lateral condyle of the femur on its posteromedial aspect (Micheo, Hernandez \& Seda, 2010). It has two bundles, anteromedial and posterolateral bundle (Norwood \& Cross, 1979).

Anterior cruciate ligament is the main brake of tibial anterior translation and secundar line of defence on forces of great intensity which work towards the formation of valgus and varus deformities (Ninković, 2011).

All ligaments, including ACL, have just like tendons, structure which is generated, i.e. formed by forces which act on them. Tendons and ligaments have the ability of morphological adaptation due to changes in their mechanical surrounding which may arise from injuries, illnesses or inadequate training.

Anatomy of the ACL has great significance in the rehabilitation and reconstruction process. An appropriate reconstruction and comprehensive recovery would eventually enable the reconstructed ACL to mimic its original anatomy as much as possible, leading to improved functionality (Markatos, Kaseta, Lallos, Korres \& Efstathopoulos, 2013).

\section{Treatment after ACL injury and safe returning to sport activities}

The main reason why is it so important to carry out rehabilitation after ACL injury is acquirement of good functional stability and bast possible level of functionallity, as well as reducement of risk for re-injury. Training programs are focused on healthy and on injured leg, then on muscles of hip and trunk which are crucial for whole body stabilisation.

Functional stability of knee joint depends on mutual influence of passive structures and dynamical systems. It is also dependent on coordination and proprioception. Deficit of 
muscle strength (Muellner, Alacamlioglu, Nikolić et al., 1998; Osteras, Augestad \& Tondel, 1998; Risberg, Holm, Tjomsland et al., 1999a; Risberg, Holm, Steen et al., 1999b; Mikkelsen, Werner \& Eriksson, 2000; Henriksson, Rockborn i Good 2002; Keays, BullockSaxton, Newcombe et al., 2003) and proprioception (Friden, Roberts, Ageberg et al., 2001) can be seen after ACL injury.

\subsection{Neuromuscular training}

The main purpose of neuromuscular training is to improve the ability of neural system to generate optimal and much faster muscle contraction, then to improve coordination and balance, as well as re-learning of certain skills and mouvement patterns (Risberg, Mork, Jenssen et al., 2001). The importance of neuromuscular training has been showed in following prospect controlled studies where the incidence of ACL injuries was much lower in athletes who undergo proprioceptive training (Caraffa, Cerulli, Projetti et al., 1996; Hewett, Lindenfeld, Riccobene et al., 1999).

Closed chain kynetics exercises had become very popular and they are very offten recomanded in rehabilitation after ACL injury because it is belived that they are much safer than the other exercises (Shelbourne i Nitz, 1990; Palmitier, An, Scott et al., 1991; Bynum, Barrack i Alexander 1995; Panni, Milano, Tartarone et al., 2001; Henriksson, Rockborn i Good 2002; Pinczewski, Deehan, Salmon et al., 2002; ; Jansson, Linko, Sandelin et al., 2003).

However, there is no enough evidence to support this statement (Beynnon \& Johnson, 1996; Fitzgerald, Axe \& Snyder-Mackler, 2000; Morrissey, Hudson, Drechsler et al., 2000; Mikkelsen, Werner i Eriksson 2000).

\subsection{Range of motion}

Most of the authors began with training for improvement of Range of motion immediate after operation. Early post-operative mobilisation of knee joint eliminates adverse effects of imobilisation on graft stifness and consecutive muscle strenght. Braces limitates range of motion and in some cases prevent antero-posterior translation. When braces were used in the first 6 weeks after surgery, there were no beneficial effects on knee joint (Nielsen \& Yde 1991; Feller, Bartlett, Chapman et al., 1997; Kartus, Stener, Kohler et al., 1997; Muellner, Alacamlioglu, Nikolić et al., 1998; Möller, Forssblad, Hansson et al., 2001).

\subsection{Full weight-bearing on injured leg}

In 21 of 34 reviewed articles, full weight-bearing on injured leg was allowed immediately after surgery, depending on pain, swelling in the injured knee joint and on degree of extension loss.

Effects of early weight-bearing on knee laxity still has not been tasted in details. Study of (Tyler, McHugh, Gleim et al., 1998) compared patients who immediately after surgery began with full weight-bearing activities with patients who started doing that 2 weeks after surgery. After 7 months of following they didn't find any differences among these two groups of patients.

\section{When to return to light and contact activities?}

Decision on weather to return to sport-specific activities or not is in most casses emirically based. Unnecessarily delaying the return to unrestricted activities is undesirable, but so is a premature return because it can lead to graf injury.

In the reviewed studies, patients were usaually allowed to return to light activities such as running at 2-3 months after surgery and to contact sports after 6 months. It is 
necessary to test musle strenght $i$ level of performances 6 months after surgery because most of athletes return to sport at this period of time.

According to IKDC (International Knee Documentation Committee) lesss than a $10 \%$ deficit at the one-leg jump test imlies to normal knee function. Of course, these limits must be considered together with other criteria for returning to sports such as asymptomatic knee (no pain or effusion, full range of motion), associated injuries and psychologial factors (Morrey, Stuart, Smith et al., 1999; Risberg, Holm, Steen et al., 1999a; Shelbourne \& Davis, 1999; Ross, Irrgang, Denegar et al., 2002).

From previous statements we can conclude that an athlete should only return to sports practices with the approval and under the supervision of their health care provider. When available, it is desireable that athletes work closely with their team's certified athletic trainer.

\section{Recommendations for return to sports}

One of the main indications for the reconstruction of ACL is that patient is being alowed to return to spot activities (Webb, Corry, Clingeleffer et al., 1998). Beside that, rate of return to a high level of athletic activity has been a critical indicator of the seccesss of ACL reconstruction (Deehan, Salmon, Webb et al., 2000).

However, the question has been raised whether the only effect of ACL reconstruction in some individuals is ,, to give the patient enough security to reach the goal of going back to strenuous sports, and then ruining the knee?" (Gillquist \& Messner, 1999).

In order to safely return to sport activities, athletes must complete rehabilitation program which is in accordiance with following requirements, presented in figure 1 of this article.

Figure 2. Factors and criteria that influence a safe return to sports

\begin{tabular}{|c|c|c|c|c|}
\hline \multirow{3}{*}{ 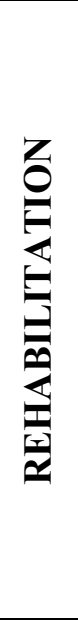 } & $\begin{array}{c}\text { Muscle strength and } \\
\text { performance } \\
\text { Evaluated by isokinetic test } \\
\text { and one leg hop test }<10-15 \% \\
\text { deficit }\end{array}$ & \multirow{2}{*}{$\begin{array}{c}\text { SAFE RETURN } \\
\text { TO SPORTS }\end{array}$} & $\begin{array}{l}\text { Social i.e. family, pregnancy, } \\
\text { finished college, etc. }\end{array}$ & \multirow{4}{*}{ 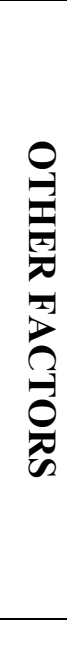 } \\
\hline & $\begin{array}{l}\text { No pain or effusion full } \\
\text { ROM } \\
\text { Evaluated by: clinical } \\
\text { examination }\end{array}$ & & $\begin{array}{l}\text { Psychological factors i.e. } \\
\text { motivation, scholarship, fear } \\
\text { of re-injury, etc. }\end{array}$ & \\
\hline & $\begin{array}{l}\text { Functional knee stability } \\
\text { Evaluated by: clinical } \\
\text { examination and objective } \\
\text { measurements ex motion } \\
\text { analysis } \\
\end{array}$ & $\begin{array}{l}\text { Static knee stability } \\
\text { Evaluated by: clinical } \\
\text { examination and } \\
\text { objective measures ex } \\
\text { KT-1000 }\end{array}$ & $\begin{array}{l}\text { Associated injuries i.e. } \\
\text { menisci, cartilage, other } \\
\text { ligaments, etc. }\end{array}$ & \\
\hline & & SURGERY & & \\
\hline
\end{tabular}

\section{CONCLUSION}

The trend in rehabilitation after ACL injury is healing towards accelerated programmes with an early return to sports. In addition, return to sport activities in considered as a valid indicator of successful treatment. However, both the question of whether the return to sport can be safe and the reason why the patient does not return to sports mus be taken into consideration. 
The goal of reconstruction is to improve stability but even after ACL reconstruction, sagittal translation may be increased. Furthermore, this is not correlated to knee function or a return to sports. Many patients can participate in sports despite a large difference in sagittal transla tion or a torn ACL, emphasising the importance of functional stability and good muscle function.

Based on current knowledge and patient compliance, some criteria should be fulfilled before allowing the patient to return to sports. These are a completed rehabilitation with adequate muscle strength and performance and as a result, knee functional stability. Surgery should result in a stable knee evaluated by static measures of sagittal translation. Other factors, such as associated injuries and social and psychological hindrances may influence the return to sports.

\section{REFERENCES}

Beard, D.J., Dodd, C.A., Trundle, H.R. et al. (1994). Proprioception enhancement for anterior cruciate ligament deficiency: a prospective randomised trial of two physiotherapy regimes. J Bone Joint Surg Br, 76(4), 654-659. PMid: 8027158

Berchuck, M., Andriacchi, T.P., Bach, B.R. et al. (1990). Gait adaptations by patients who have a deficient anterior cruciate ligament. J Bone Joint Surg Am, 72(6), 871-877. https://doi.org/10.2106/00004623-199072060-00012

PMid:2365720

Beynnon, B.D. \& Johnson, R.J. (1996). Anterior cruciate ligament injury rehabilitation in athletes: biomechanical considerations. Sports Med, 22(1), 54-64.

https://doi.org/10.2165/00007256-199622010-00005 PMid:8819240

Bjordal, J.M., Arnly, F., Hannestad, B. et al. (1997). Epidemiology of anterior cruciate ligament injuries in soccer. Am J Sports Med, 25(3), 341-345.

https://doi.org/10.1177/036354659702500312

PMid:9167814

Bynum, E.B., Barrack, R.L. \& Alexander, A.H. (1995). Open versus closed chain kinetic exercises after anterior cruciate ligament reconstruction: a prospective randomized study. Am J Sports Med, 23(4), 401-406. https://doi.org/10.1177/036354659502300405

PMid:7573647 
Caraffa, A., Cerulli, G., Projetti, M. et al. (1996). Prevention of anterior cruciate ligament injuries in soccer: a prospective controlled study of proprioceptive training. Knee Surg Sports Traumatol Arthrosc, 4(1), 19-21.

https://doi.org/10.1007/BF01565992

PMid:8963746

Deehan, D.J., Salmon, L.J., Webb, V.J. et al. (2000). Endoscopic reconstruction of the anterior cruciate ligament with an ipsilateral patellar tendon autograft: a prospective longitudinal five-year study. J Bone Joint Surg Br, 82(7), 984-991.

https://doi.org/10.1302/0301-620X.82B7.10573

PMid:11041586

Feller, J., Bartlett, J., Chapman, S., et al. (1997). Use of an extension-assisting brace following anterior cruciate ligament reconstruction. Knee Surg Sports Traumatol Arthrosc, 5(1), 6-9.

https://doi.org/10.1007/s001670050016

PMid:9127846

Fitzgerald, G.K., Axe, M.J. \& Snyder-Mackler, L. (2000). The efficacy of perturbation training in nonoperative anterior cruciate ligament rehabilitation programs for physical active individuals. Phys Ther, 80(2), 128-140.

PMid: 10654060

Friden, T., Roberts, D., Ageberg, E. et al. (2001). Review of knee proprioception and the relation to extremity function after an anterior cruciate ligament rupture. J Orthop Sports Phys Ther, 31(10), 567-576.

https://doi.org/10.2519/jospt.2001.31.10.567

PMid:11665744

Fulkerson, J. \& Hungerford, D. (1990). Normal anatomy. In Disordersof the Patellofemoral Joint. Baltimore, USA.

Gillquist, J. \& Messner, K. (1999). Anterior cruciate ligament reconstruction and the longterm incidence of gonarthrosis. Sports Med, 27(3), 143-156.

https://doi.org/10.2165/00007256-199927030-00001

PMid:10222538

Henriksson, M., Rockborn, P. \& Good, L. (2002). Range of motion training in brace vs plaster immobilization after anterior cruciate ligament reconstruction: a prospective randomized comparison with a 2-year follow-up. Scand J Med Sci Sports, 12(2), 7380 .

https://doi.org/10.1034/j.1600-0838.2002.120203.x

PMid:12121424

Hewett, T.E., Lindenfeld, T.N., Riccobene, J.V. et al. (1999). The effect of neuromuscular training on the incidence of knee injury in female athletes: a prospective study. Am J Sports Med, 27(6), 699-706.

PMid:10569353

Jansson, K.A., Linko, E., Sandelin, J. et al. (2003). A prospective randomized study of patellar versus hamstring tendon autografts for anterior cruciate ligament reconstruction. Am J Sports Med, 31(1), 12-18.

PMid:12531751

Kartus, J., Stener, S., Kohler, K. et al. (1997). Is bracing after anterior cruciate ligament reconstruction necessary?: a 2-year follow-up of 78 consecutive patients rehabilitated with or without a brace. Knee Surg Sports Traumatol Arthrosc, 5(3), $157-161$.

https://doi.org/10.1007/s001670050044

PMid:9335027 
Keays, S.L., Bullock-Saxton, J.E., Newcombe, P. et al. (2003). The relationship between knee strength and functional stability before and after anterior cruciate ligament reconstruction. J Orthop Res,21(2), 231-237.

https://doi.org/10.1016/S0736-0266(02)00160-2

Kvist, J. \& Gillquist, J. (2001). Anterior positioning of tibia during motion after anterior cruciate ligament injury. Med Sci Sports Exerc, 33(7), 1063-1072.

https://doi.org/10.1097/00005768-200107000-00001

PMid:11445751

Markatos, K., Kaseta, M.K., Lallos, S.N., Korres, D.S. \& Efstathopoulos, N. (2013). The anatomy of the ACL and its importance in ACL reconstruction. Eur J Orthop Surg Traumatol., 23(7), 747-752.

https://doi.org/10.1007/s00590-012-1079-8

PMid:23412211

Mikkelsen, C., Werner, S. \& Eriksson, E. (2000). Closed kinetic chain alone compared to combined open and closed kinetic chain exercises for quadriceps strengthening after anterior cruciate ligament reconstruction with respect to return to sports: a prospective matched follow-up study. Knee Surg Sports Traumatol Arthrosc, 8(6), 337-342.

https://doi.org/10.1007/s001670000143

PMid:11147151

Micheo, W., Hernandez, L. \& Seda, C. (2010). Evaluation, management, rehabilitation, and prevention of anterior cruciate ligament injury: current concepts. $P M R$., 2(10), $935-$ 944.

https://doi.org/10.1016/j.pmrj.2010.06.014

PMid:20970763

Möller, E., Forssblad, M., Hansson, L. et al. (2001). Bracing versus nonbracing in rehabilitation after anterior cruciate ligament reconstruction: a randomized prospective study with 2-year follow-up. Knee Surg Sports Traumatol Arthrosc, 9(2), 102-108.

https://doi.org/10.1007/s001670000192

PMid:11354851

Morrey, M.A., Stuart, M.J., Smith, A.M. et al. (1999). A longitudinal examination of athletes' emotional and cognitive responses to anterior cruciate ligament injury. Clin J Sport Med, 9(2), 63-69.

https://doi.org/10.1097/00042752-199904000-00004

PMid:10442619

Morrissey, M.C., Hudson, Z.L., Drechsler, W.I. et al. (2000). Effects of open versus closed kinetic chain training on knee laxity in the early period after anterior cruciate ligament reconstruction. Knee Surg Sports Traumatol Arthrosc, 8(6), 343-348. https://doi.org/10.1007/s001670000161

PMid:11147152

Muellner, T., Alacamlioglu, Y., Nikolic, A. et al. (1998). No benefit of bracing on the early outcome after anterior cruciate ligament reconstruction. Knee Surg Sports Traumatol Arthrosc, 6(2), 88-92.

https://doi.org/10.1007/s001670050078

PMid:9604192

Myklebust, G., Maehlum, S., Engebretsen, L. et al. (1997). Registration of cruciate ligament injuries in Norwegian top level team handball: a prospective study covering two seasons. Scand J Med Sci Sports, 7(5), 289-292. 
https://doi.org/10.1111/j.1600-0838.1997.tb00155.x

PMid:9338947

Nielsen, A.B. \& Yde, J. (1991). Epidemiology of acute knee injuries: a prospective hospital investigation. J Trauma, 31(12), 1644-1648.

https://doi.org/10.1097/00005373-199112000-00014

PMid:1749037

Ninković S. (2011). Uvećanje koštanog kanala u butnoj kosti i golenjači nakon rekonstrukcije prednjeg ukrštenog ligamenta kolena. Doktroska disertacija, Univerzitet u Novom Sadu, Medicinski fakultet Novi Sad.

Norwood, L. \& Cross, M. (1979). Anterior cruciate ligament: functional anatomy of its bundles in rotatory instabilities. Am J Sports Med., (7), 23-26.

https://doi.org/10.1177/036354657900700106

PMid:420384

Osteras, H., Augestad, L.B. \& Tondel, S. (1998). Isokinetic muscle strength after anterior cruciate ligament reconstruction. Scand J Med Sci Sport, 8 (5), 279-282. https://doi.org/10.1111/j.1600-0838.1998.tb00483.x

Palmitier, R.A., An, K.N., Scott, S.G. et al. (1991). Kinetic chain exercise in knee rehabilitation. Sports Med, 11(6), 402-413.

https://doi.org/10.2165/00007256-199111060-00005

PMid:1925185

Panni, A.S., Milano, G., Tartarone, M. et al. (2001). Clinical and radiographic results of ACL reconstruction: a 5- to 7-year follow-up study of outside-in versus inside-out reconstruction techniques. Knee Surg Sports Traumatol Arthrosc; 9(2), 77-85.

https://doi.org/10.1007/s001670000171

PMid:11354857

Pinczewski, L.A., Deehan, D.J., Salmon, L.J. et al. (2002). A five-year comparison of patellar tendon versus four-strand hamstring tendon autograft for arthroscopic reconstruction of the anterior cruciate ligament. Am J Sports Med, 30(4), 523-536. PMid: 12130407

Risberg, M.A., Holm, I., Steen, H. et al. (1999a). The effect of knee bracing after anterior cruciate ligament reconstruction: a prospective, randomized study with two years' follow-up. Am J Sports Med, 27(1), 76-83.

PMid:9934423

Risberg, M.A., Holm, I., Tjomsland, O. et al. (1999b). Prospective study of changes in impairments and disabilities after anterior cruciate ligament reconstruction. J Orthop Sports Phys Ther, 29(7), 400-412.

https://doi.org/10.2519/jospt.1999.29.7.400

PMid:10416180

Risberg, M.A., Mork, M., Jenssen, H.K. et al. (2001). Design and implementation of a neuromuscular training program following anterior cruciate ligament reconstruction. J Orthop Sports Phys Ther., 31(11), 620-631.

https://doi.org/10.2519/jospt.2001.31.11.620

PMid:11720295

Roos, H., Ornell, M., Gardsell, P. et al. (1995). Soccer after anterior cruciate ligament injury: an incompatible combination?: a national survey of incidence and risk factors and a 7-year follow-up of 310 players. Acta Orthop Scand, 66(2), 107-112.

https://doi.org/10.3109/17453679508995501

PMid:7740937 
Ross, M.D., Irrgang, J.J., Denegar, C.R. et al. (2002). The relationship between participation restrictions and selected clinical measures following anterior cruciate ligament reconstruction. Knee Surg Sports Traumatol Arthrosc, 10(1), 10-19.

https://doi.org/10.1007/s001670100238

PMid:11819015

Shelbourne, K.D. \& Davis, T.J. (1999). Evaluation of knee stability before and after participation in a functional sports agility program during rehabilitation after anterior cruciate ligament reconstruction. Am J Sports Med, 27(2), 156-161. PMid:10102094

Shelbourne, K.D. \& Nitz, P. (1990). Accelerated rehabilitation after anterior cruciate ligament reconstruction. Am J Sports Med., 18(3), 292-299.

https://doi.org/10.1177/036354659001800313 PMid:2372081

Tyler, T., McHugh, M., Gleim, G. et al. (1998). The effect of immediate weightbearing after anterior cruciate ligament reconstruction. Clin Orthop., (357), 141-148. https://doi.org/10.1097/00003086-199812000-00019

Webb, J.M., Corry, I.S., Clingeleffer, A.J. et al. (1998). Endoscopic reconstruction for isolated anterior cruciate ligament rupture. J Bone Joint Surg Br., 80(2), 288-294. https://doi.org/10.1302/0301-620X.80B2.7994

PMid:9546463

Received: 04.05.2017.

Accepted: 26.06.2017.

Correspondence author:

Dejan Ilić, PhD

Faculty of Sport and Physical Education University of Belgrade

Blagoja Parovića 156 11030 Belgrade Serbia

Tel:+381(11)3531-000

dejan.ilic@,fsfv.bg.ac.rs 